\title{
Presynaptic Actions of 4-Aminopyridine and $\gamma$-Aminobutyric Acid on Rat Sympathetic Ganglia in vitro
}

\author{
M. Galvan, P. Grafe, and G. ten Bruggencate \\ Physiologisches Institut der Universität München, Pettenkoferstrasse 12, 8000 München 2, Federal Republic of Germany
}

Summary. Responses to bath-applications of 4-aminopyridine (4-AP) and $\gamma$-aminobutyric acid (GABA) were recorded intracellularly from neurones in the rat isolated superior cervical ganglion.

4-aminopyridine $(0.1-1.0 \mathrm{mmol} / \mathrm{l})$ usually induced spontaneous action potentials and excitatory postsynaptic potentials (EPSPs), which were blocked by hexamethonium. Membrane potential was unchanged; spike duration was slightly increased. Vagus nerve $\mathrm{B}$-and C-fibre potentials were prolonged.

In 4-AP solution $(0.1-0.3 \mathrm{mmol} / 1), \quad$ GABA $(0.1 \mathrm{mmol} / \mathrm{l}), 3$-aminopropanesulphonic acid or muscimol evoked "bursts" of spikes and EPSPs in addition to a neuronal depolarization. These "bursts", which were not elicited by glycine, glutamate, taurine or $( \pm)$-baclofen, were completely antagonised by hexamethonium, tetrodotoxin or bicuculline methochloride.

It is concluded that: (a) 4-AP has a potent presynaptic action on sympathetic ganglia; (b) presynaptic actions of GABA can be recorded postsynaptically in the presence of 4-AP; and (c) the presynaptic GABAreceptors revealed in this condition are similar to those on the postsynaptic membrane.

Key words: 4-Aminopyridine - GABA - Sympathetic ganglion - Presynaptic receptors.

\section{Introduction}

Receptors for $\gamma$-aminobutyric acid (GABA), an inhibitory transmitter in the mammalian central nervous system, are also present on neurones in mammalian sympathetic ganglia (see Nistri and Constanti 1979 for a recent review). GABA receptors also exist on un-

Send offprint requests to $\mathrm{M}$. Galvan at the above address myelinated axons in the sympathetic preganglionic nerve (Brown and Marsh 1978). Additionally, it has recently been suggested that on the nerve terminals there exists a further population of GABA-receptors, the activation of which leads to a reduction in acetylcholine release (Brown and Higgins 1979). Such receptors on autonomic nerve terminals have been reported to be bicuculline-insensitive and to be activated by the anti-spastic drug baclofen (Bowery et al. 1979).

Efforts to demonstrate electrophysiologically presynaptic effects of GABA in intact ganglia are hampered by the strong postsynaptic inhibitory action of this compound. Kato and Kuba (1980) partially overcame this problem by carefully comparing the time courses of the GABA-induced postsynaptic conductance increase and depression of the excitatory postsynaptic potential amplitude in bullfrog sympathetic ganglia. In this paper, we report that in the presence of 4-aminopyridine (4-AP), presynaptic actions of GABA can be clearly observed whilst recording intracellularly from the postganglionic neurones. 4-aminopyridine, which is known to act as an axonal $\mathrm{K}^{+}$-channel blocker (Schauf et al. 1976; Ulbricht and Wagner 1976; Yeh et al. 1976a; Meves and Pichon 1977), has been reported to greatly enhance presynaptic excitability, although the mechanism of this effect is, as yet, unclear (Lemeignan 1972, 1973).

The present experiments were performed with two questions in mind. First, to what extent does 4-AP affect pre- and postsynaptic function in isolated rat sympathetic ganglia? Second, what is the nature of the presynaptic GABA receptors?

\section{Methods}

Wistar rats, either sex (approximately $300 \mathrm{~g}$ ) were anaesthetized with urethane $(1.5 \mathrm{~g} / \mathrm{kg}$; i.p.) and the superior cervical ganglia were removed. After dissecting free the connective tissue sheath, ganglia were placed in a small Perspex bath and superfused with Krebs' solution at $5-10 \mathrm{ml} / \mathrm{min}$, gassed with $95 \% \mathrm{O}_{2} / 5 \% \mathrm{CO}_{2}$. The pre- and 
postganglionic nerves were drawn into glass suction electrodes, which permitted orthodromic nervous stimulation $(10-20 \mathrm{~V}, 0.1 \mathrm{~ms})$ and also served to hold the preparation stable on the floor of the bath. The Krebs' solution contained (mmol/l): $\mathrm{NaCl}, 118 ; \mathrm{KCl}, 4.8 ; \mathrm{CaCl}, 2.5$ $\mathrm{NaHCO}_{3}, 25 ; \mathrm{KH}_{2} \mathrm{PO}_{4}, 1.2 ; \mathrm{MgSO}_{4}, 1.2 ; \mathrm{D}$-glucose, 11.16 experiments were performed at $30^{\circ} \mathrm{C}$ and 11 at $25^{\circ} \mathrm{C}$; all drugs were applied via the superfusate.

Intracellular recordings were obtained from 36 neurones in 27 ganglia using a single resistance- and capacitance-compensated microelectrode coupled to an amplifier capable of delivering constant-current pulses. Electrodes were filled with neutralised $4 \mathrm{M}$ potassium acetate $(\mathrm{pH}=7.4$; Brown and Constanti 1978) and had resistances between 60 and $120 \mathrm{M} \Omega$. Only cells with stable resting potentials and action potentials $\geq 60 \mathrm{mV}$ were selected for study. Potentials were displayed on an oscilloscope and a potentiometric chart recorder and also stored on magnetic tape for further analysis. The frequency of action potentials was measured "off line" using a Nicolet Med 80 computer. Extracellular d.c. recording from ganglia was performed at room temperature $\left(\approx 20^{\circ} \mathrm{C}\right)$ using an "air gap" method (Brown and Marsh 1975).

In a number of experiments, instead of the superior cervical ganglion the cervical vagus nerve was removed (care being taken to exclude the nodose ganglion). After desheathing, both ends of the nerve were gently pulled into suction electrodes and stimulus parameters were selected to elicit either $\mathrm{A}$ and $\mathrm{B}$ fibre compound potentials or A, B and C fibre potentials (see Douglas and Ritchie 1957). Nerves were maintained in flowing Krebs' solution (see above) at $30^{\circ} \mathrm{C}$. Compound action potentials were recorded with a d.c. coupled oscilloscope and averaged using a digital averager (Didac $800)$.

Drug sources were as follows: $\gamma$-aminobutyric acid, L-glutamate $\mathrm{Na}$, glycine and tetrodotoxin (Sigma); taurine and hexamethonium bromide (Merck, Darmstadt, FRG); 4-aminopyridine (EGAChemie, Steinheim, FRG); 3-aminopropanesulphonic acid (K\&K Laboratories). Biocuculline methochloride was kindly prepared from bicuculline by Dr. Klosa. Muscimol $\mathrm{HCl}$ was donated by Schering A.G., Berlin; baclofen was donated by Ciba-Geigy, Basel, Switzerland.

\section{Results}

Actions of 4-Aminopyridine

The most obvious effect of 4-aminopyridine (4-AP) on sympathetic neurones was a dramatic increase in spontaneous synaptic activity. Thus, after several minutes of superfusion with solutions containing $0.1-$ $1 \mathrm{mmol} / 14$-AP, 25 out of 36 cells exhibited spontaneous excitatory postsynaptic potentials (EPSPs) as well as action potentials (Fig. 1A and B). Although the concentration-dependency of this effect was not systematically investigated, it was usually the case that $1 \mathrm{mmol} / 1 \mathrm{4}$-AP was more effective in eliciting spontaneous potentials. In the experiment illustrated in Fig. $1 \mathrm{C}$, addition of $1 \mathrm{mmol} / \mathrm{l} 4 \mathrm{AP}$ caused the cell to discharge at a frequency approaching $3 \mathrm{~Hz}$. This spontaneous firing, which was reversibly abolished by the nicotinic receptor antagonist hexamethonium (Fig. 1C), ceased after about $12 \mathrm{~min}$ washing in normal Krebs' solution. In the presence of hexamethonium, action potentials could still be elicited by injecting depolarizing current across the cell membrane (see inset Fig. 1C).

Table 1 summarizes the effects of 4-AP $(0.1-$ $1 \mathrm{mmol} / \mathrm{l})$ on membrane potential, input resistance and action potential duration. No marked changes in resting potential were observed. Changes in input resistance (calculated from electrotonic potential amplitudes produced by constant-current pulses) were inconsistant; we observed either no change, increases or decreases of up to $25 \%$. The action potential
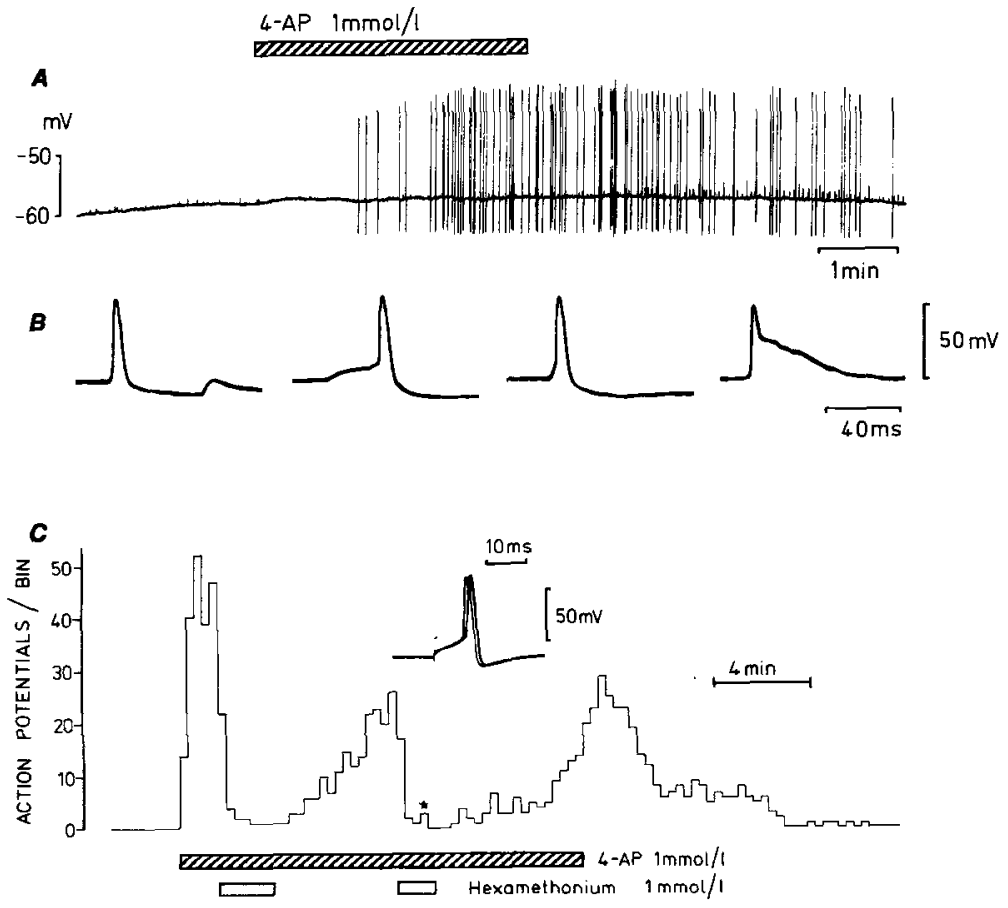

Fig. $1 \mathrm{~A}-\mathrm{C}$

Spontaneous synaptic activity recorded from sympathetic neurones during the action of 4 aminopyridine (4-AP). Part (A) shows the effect of a $3.5 \mathrm{~min}$ application of $1 \mathrm{mmol} / 14$-AP (hatched bar) on the membrane potential. After a latency of about $1 \mathrm{~min}$, during which there was virtually no change in resting potential, the cell began to fire spontaneously. Examples of spontaneous discharges are shown in (B). The amplitude of the action potentials in (A) was attenuated because of the chart recorder response time; temperature was $25^{\circ} \mathrm{C}$. Part (C) illustrates the effect of hexamethonium ( $1 \mathrm{mmol} / \mathrm{l}$; open bars) on $4 \mathrm{AP}$ induced neuronal action potentials. The frequency of intracellularly-recorded spontaneous action potentials is shown on the ordinates; bin width was $20 \mathrm{~s}$. The inset shows three spikes, which were elicited during hexamethonium by injecting depolarizing current across the cell membrane; the asterisk indicates their occurrence in the histogram. Temperature was $30^{\circ} \mathrm{C}$ 
Table 1. Effects of 4-aminopyridine on membrane potential $\left(E_{m}\right)$, membrane resistance $\left(R_{m}\right)$ and action potential duration (AP dur), measured $5-15 \mathrm{~min}$ after drug application

\begin{tabular}{lccccccc}
\hline $\begin{array}{l}\text { Concentration } \\
\text { mmol/1 }\end{array}$ & Cell No. ${ }^{\mathrm{a}}$ & $E_{m} \mathrm{mV}$ & $\Delta E_{m} \mathrm{mV}$ & $R_{m}{ }^{\mathrm{b}} \mathrm{M} \Omega$ & $\Delta R_{m} \%$ & $\mathrm{AP}^{\mathrm{c}} \mathrm{dur} \mathrm{ms}$ & $\Delta \mathrm{AP}$ dur $\%$ \\
\hline 0.1 & 2 & -50 & 0 & 40 & 0 & 2.0 & +20 \\
0.1 & 3 & -60 & +2 & 100 & +10 & 1.6 & +31 \\
0.3 & 1 & -50 & -2 & 50 & -20 & 1.8 & +11 \\
0.3 & 4 & -55 & +2 & 47 & -9 & 2.0 & +20 \\
0.3 & 5 & -48 & +3 & 19 & -16 & 2.1 & +11 \\
1.0 & 4 & -60 & -2 & 50 & -13 & 2.1 & +52 \\
1.0 & 5 & -47 & -3 & 15 & +23 & 1.9 & +63 \\
1.0 & 6 & -50 & +2 & 52 & & +6 \\
\hline
\end{tabular}

a Data analysis restricted to 6 cells with stable resting potential and input resistance

b Calculated from potential deflections produced by $0.4 \mathrm{nA}$ hyperpolarizing constant-current pulses

- Measured as the duration at $50 \%$ of total action potential amplitude

duration was significantly increased by up to $63 \%$, whereas action potential amplitude was usually unaffected. The increased duration was mainly due to a prolongation of the repolarizing phase of the spike (Fig. 2A; see also McAfee and Yarowsky 1979). The amplitude and overall duration of postsynaptic potentials induced by orthodromic nerve stimulation was unaffected by $100 \mu \mathrm{mol} / 1$ 4-AP (Fig. 2B).

Extracellular d.c. recordings revealed that $0.1-$ $1.0 \mathrm{mmol} / 1$ of $4-\mathrm{AP}$ either induced small ganglionic positivities or negativities. However, higher concentrations $(3-10 \mathrm{mmol} / \mathrm{l})$ always induced negativities suggesting a depolarization of the postganglionic neurones (see also Hue et al. 1978).

In addition to the experiments on sympathetic ganglia, the action of $100 \mu \mathrm{mol} / 14-\mathrm{AP}$ was tested on the isolated vagus nerve ( 9 preparations). The following effects on the compound action potential were observed: (1) the A-fibre potential was unaltered (Fig. 2C). (2) The B-and C-fibre potentials were clearly increased in duration (Fig. 2D). These effects were observed within $2-5 \mathrm{~min}$ and were reversible by washing for about $30 \mathrm{~min}$.

\section{Actions of $G A B A$ in 4-Aminopyridine}

Figure 3 illustrates the action of $100 \mu \mathrm{mol} / 1 \mathrm{GABA}$ in normal Krebs' solution and during superfusion with $100 \mu \mathrm{mol} / 1$ 4-AP. In the control (Fig. 3A), application of GABA resulted in a reversible neuronal depolarization as previously described (Adams and Brown 1975). The ganglion was then superfused with $100 \mu \mathrm{mol} / 1 \mathrm{4}$-AP for $10 \mathrm{~min}$ and GABA reapplied. In the 4-AP solution, GABA additionally elicited a "burst" of action potentials as well as some EPSPs. This effect was reversible after washing in normal Krebs' solution for 10 min (Fig. 3C). Examples of subthreshold potentials and action potentials (which were often preceded or followed by synaptic potentials) are

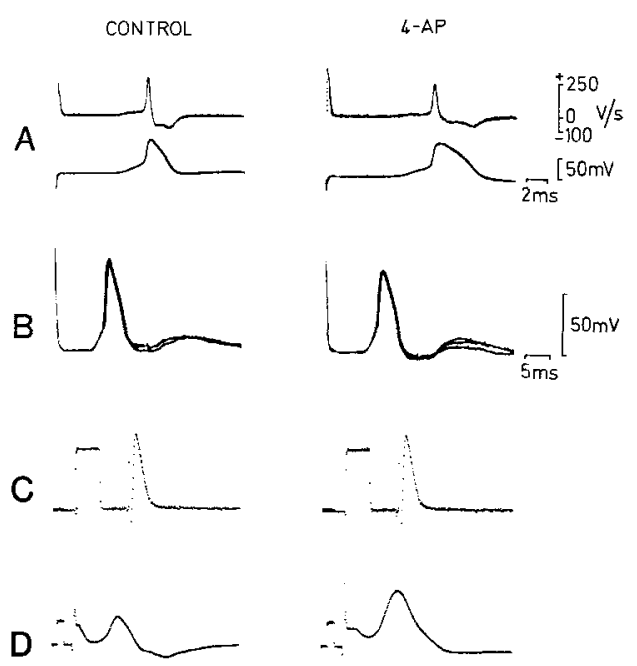

Fig. 2. Effects of 4-aminopyridine (4-AP) on (A) soma spike duration, (B) responses to orthodromic nerve stimulation, (C) and (D) the compound action potential of an isolated vagus nerve. The left panel in (A) shows the soma spike and its first time derivative (top trace). The right panel was recorded $15 \mathrm{~min}$ after addition of $1 \mathrm{mmol} / 14-\mathrm{AP}$; note the decreased rate of rise and marked prolongation of the repolarizing phase. Temperature was $30^{\circ} \mathrm{C}$. In (B) (different ganglion) postsynaptic responses to orthodromic nerve stimulation are shown; control (left), and $10 \mathrm{~min}$ after addition of $100 \mu \mathrm{mol} / \mathrm{l}$ 4-AP (right). In each example, 3 responses are photographically superimposed. Resting potential was about $-50 \mathrm{mV}$; temperature was $30^{\circ} \mathrm{C}$. Parts (C) and (D) illustrate the effect of $100 \mu \mathrm{mol} / 14-\mathrm{AP}$ on vagus nerve compound potentials. In each case 10 responses were averaged in control solution (left panel) and 5 min after application of 4-AP (right panel). The stimulation parameters were as follows: Afibre potential $(\mathrm{C}), 0.5 \mathrm{~Hz}, 10 \mu \mathrm{s}$, supramaximal voltage; C-fibre potential $(\mathrm{D}), 0.5 \mathrm{~Hz}, 100 \mu \mathrm{s}$, supramaximal voltage. Calibration pulse : $2 \mathrm{mV}, 1 \mathrm{~ms}$

shown in Fig. 3B2 and 3B 3 respectively. In 8 other neurones, in all of which 4-AP alone produced no spontaneous activity, GABA had a similar effect to that illustrated in Fig. 3. In 13 out of 19 other cells, which exhibited spontaneous activity in 4-AP $(100-$ $300 \mu \mathrm{mol} / \mathrm{l})$, GABA clearly increased the frequency of 


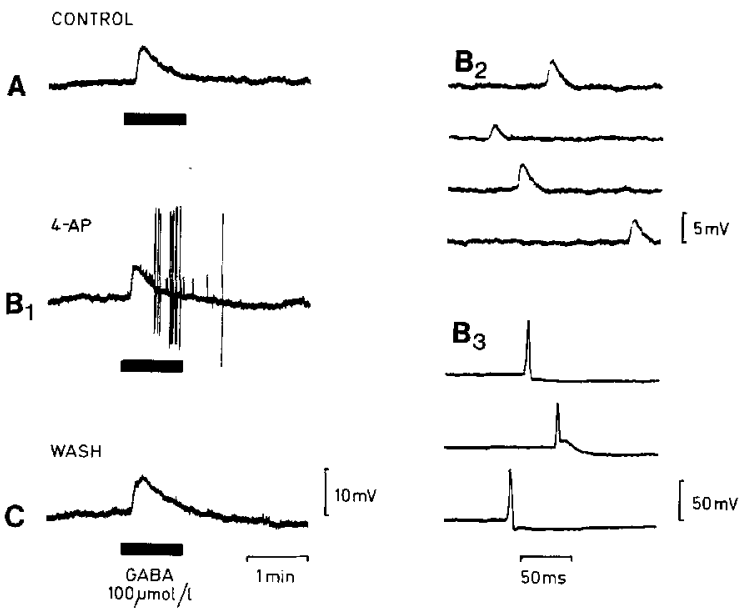

Fig. 3. Effect of $100 \mu \mathrm{mol} / 1 \mathrm{GABA}$ (solid bar) on the membrane potential of a ganglion cell (A) in control solution, (B) $10 \mathrm{~min}$ after addition of $100 \mu \mathrm{mol} / 1$ 4-aminopyridine (4-AP) and (C) $10 \mathrm{~min}$ after washing in normal solution. In the presence of 4-AP, GABA evoked a "burst" of subthreshold potentials and action potentials, examples of which are shown in $B_{2}$ and $B_{3}$ respectively. The amplitude of the action potentials in $B_{1}$ is attenuated by the chart recorder. Resting membrane potential of this cell was about $-50 \mathrm{mV}$; temperature was $30^{\circ} \mathrm{C}$ these events (see Fig. 5B). It was often observed that the maximum frequency of GABA-induced postsynaptic potentials occurred towards the end of, and immediately following GABA superfusion, rather than at the peak of the postsynaptic depolarization (see Fig. 3B1). Intracellular records showed that the amplitude of the GABA-induced soma depolarization was not significantly altered in 4-AP solution (Fig. 3). However, using extracellular d.c. recording, we found that the depolarizing action of $100 \mu \mathrm{mol} / 1 \mathrm{GABA}$ was slightly reduced in the presence of $300 \mu \mathrm{mol} / 14$-AP $(-10 \%$; mean of 3 experiments). Experiments performed at $25^{\circ} \mathrm{C}$ were qualitatively similar to those at $30^{\circ} \mathrm{C}$.

In order to determine the origin of the postsynaptic potentials elicited by GABA during 4-AP superfusion, we examined their sensitivity to hexamethonium and tetrodotoxin (TTX). In all 6 cells tested, hexamethonium $(0.5-2 \mathrm{mmol} / \mathrm{l})$ completely abolished action potentials and EPSPs induced by GABA in the presence of 4-AP (Fig. 4). Tetrodotoxin ( $350 \mathrm{nmol} / 1)$, a concentration sufficient to block $\mathrm{Na}^{+}$-mediated action potentials, also abolished action potentials and, more

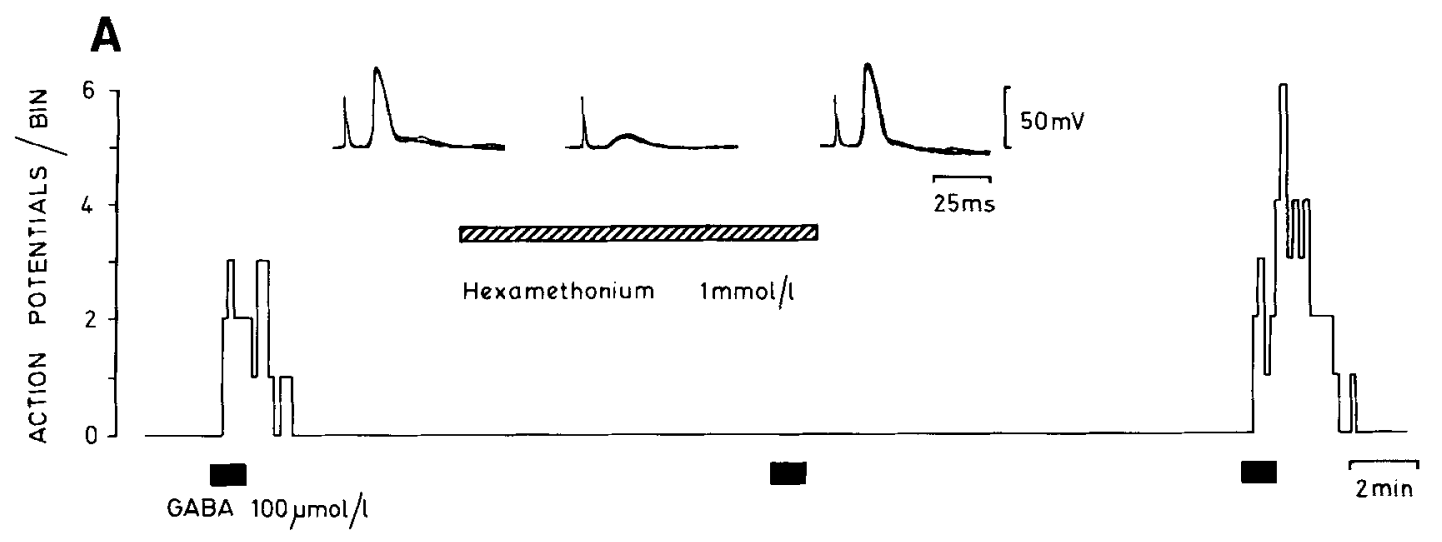

B

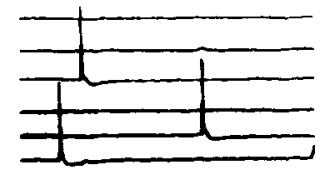

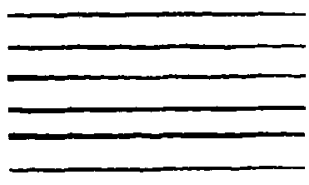

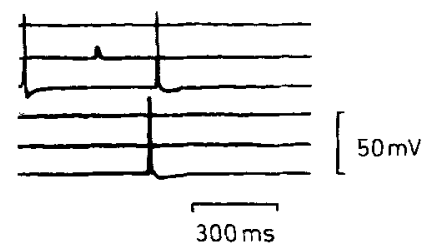

Fig. 4 A and B. Action of hexamethonium on the action potentials induced by GABA in 4-aminopyridine solution. The recording in (A), which started $8 \mathrm{~min}$ after addition of 4-AP $(300 \mu \mathrm{mol} / \mathrm{l})$, shows the computer plot of the frequency of action potentials (ordinate) recorded from the cell soma. The first application of GABA (solid bar) elicited a number of spikes; this effect was reversibly blocked by hexamethonium (hatched bar). The insets show responses to orthodromic stimulation ( 3 sweeps superimposed) recorded before, during and after hexamethonium and illustrate that synaptically-evoked action potentials could not be generated in the presence of hexamethonium. Bin width was $10 \mathrm{~s}$. Part (B) shows examples of postsynaptic potentials evoked during the $3 \mathrm{GABA}$ applications. Note that in addition to action potentials, there were some subthreshold potentials which were not counted and displayed in part (A). Resting potential of this cell was uncertain due to DC drifts; temperature was $30^{\circ} \mathrm{C}$ 


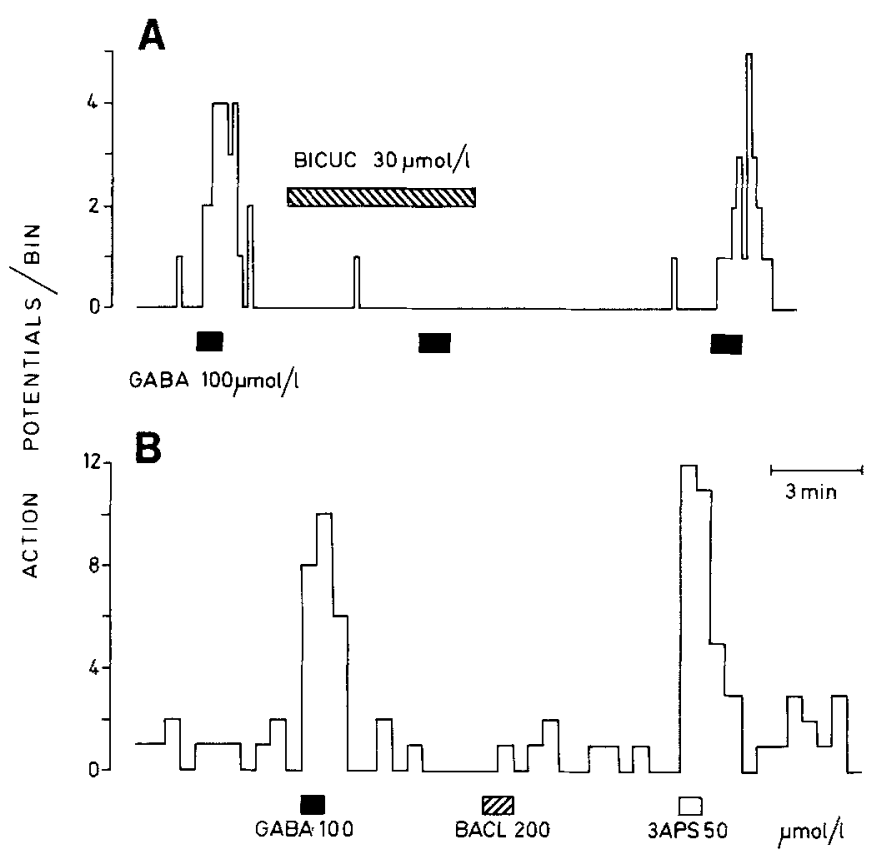

Fig. 5A and B. Actions of bicuculline, GABA and some GABAmimetics in 4-aminopyridine solution. Computer plots of the occurrance of action potentials recorded intracellularly from two sympathetic neurones in different ganglia (both at $30^{\circ} \mathrm{C}$ ). The ordinates indicate the frequency of action potentials; bin width in (A) was $10 \mathrm{~s}$ and in (B) $30 \mathrm{~s}$. Note different scales in (A) and (B). The recording in A shows that the GABA-induced "bursts" of action potentials were reversibly blocked by application of $30 \mu \mathrm{mol} / 1$ bicuculline methochloride (hatched bar). The recording in (B) was obtained from a neurone that was spontaneously active in the presence of 4-aminopyridine $(100 \mu \mathrm{mol} / 1)$. The section shown illustrates that brief applications of $100 \mu \mathrm{mol} / 1 \mathrm{GABA}$ (solid bar) or $50 \mu \mathrm{mol} / 1 \mathrm{l}$-aminopropanesulphonic acid (3-APS; open bar) greatly increased the firing frequency, whereas $200 \mu \mathrm{mol} / 1$ baclofen (BACL; hatched bar) had no such effect

important, subthreshold EPSPs induced by GABA in 4-AP (5 cells).

\section{Effects of Bicuculline and some GABA-Mimetics}

Figure 5 illustrates the results of experiments performed to characterize the GABA receptor responsible for the effects described. For simplicity, only the computer counts of postsynaptic action potentials are shown.

Part A was recorded $45 \mathrm{~min}$ after addition of $300 \mu \mathrm{mol} / 1 \mathrm{H}$-AP to the superfusate. The first application of GABA clearly increased the frequency of spikes, an effect which was reversibly antagonised by $30 \mu \mathrm{mol} / 1$ bicuculline methochloride (4 cells).

Part B (different ganglion) was recorded $50 \mathrm{~min}$ after addition of $100 \mu \mathrm{mol} / 14-\mathrm{AP}$ and shows that the action of GABA was powerfully replicated by 3-aminopropanesulphonic acid (3-APS) but not by baclofen.
From a number of such experiments, it was observed that the action of $100 \mu \mathrm{mol} / \mathrm{l} \mathrm{GABA}$ in 4 -AP was mimicked by 3 -APS ( $30-50 \mu \mathrm{mol} / 1 ; 9$ cells tested) and muscimol $(50 \mu \mathrm{mol} / 1 ; 3$ cells $)$, but not by baclofen $(100-200 \mu \mathrm{mol} / 1 ; 8$ cells $)$, glutamate, glycine or taurine (all $1 \mathrm{mmol} / 1 ; 2$ cells). The latter 4 compounds did not change the neuronal resting membrane potential.

\section{Discussion}

\section{a) 4-Aminopyridine}

4-aminopyridine has been reported to have several powerful effects on synaptic function. These include (a) an enhancement of stimulus-induced transmitter release in the cat spinal cord (Lemeignan 1972, 1973; Jankowska et al. 1977), rat neuromuscular junction (Lundh 1978) and squid giant synapse (Llinás et al. 1976). (b) An induction of spontaneous transmitter release at the neuromuscular junction (Bowman et al. 1977; Marshall et al. 1979; however, see also Lundh 1978). (c) An increase in stimulus-induced changes of extracellular $\mathrm{K}^{+}$and $\mathrm{Ca}^{2+}$ activities in cat cerebellum (Nicholson et al. 1976). (d) A marked increase in the number of vesicle attachment sites in freeze fracture preparations of rat motoneurones (Tokunaga et al. 1979; see also Heuser et al. 1979).

A further effect of 4-AP, observed in squid axons, is the appearance of spontaneous membrane potential oscillations and action potentials (Llinás et al. 1976; Yeh et al. 1976b; Golenhofen and Mandrek 1978). In the present experiments on rat sympathetic neurones, the induction of spontaneous action potentials, as well as subthreshold EPSPs were also observed. Since these effects were not accompanied by a marked change in membrane potential, and were blocked by hexamethonium, they most likely arise as a result of acetylcholine release from presynaptic nerve terminals. The fact that these potentials were suppressed by TTX suggests that the acetylcholine release was actionpotential-dependent (see also Yanagisawa et al. 1978). However, it should be noted that electrotonic depolarization of nerve terminals is sufficient to release neurotransmitter (Katz and Miledi 1969; Lundh and Thesleff 1977). Thus it is possible that axonal membrane potential oscillations alone could lead to acetylcholine release. In squid axons, 4-AP-induced oscillations were partially blocked by tetrodotoxin and for this reason it cannot be firmly concluded that the acetylcholine release we observed was dependent on the invasion of action potentials into the synaptic terminals.

In agreement with McAfee and Yarowski (1979), we found small increases in the duration of the repolarizing phase of the action potential, suggesting that the outward $\mathrm{K}^{+}$current was partially blocked. In 
addition, $100 \mu \mathrm{mol} / 14$-AP clearly enhanced the duration of the $\mathrm{B}$ - and $\mathrm{C}$-fibre compound potentials in the isolated vagus nerve. The lack of effect on the vagus A-fibre potential may be explained by an absence of repolarizing potassium currents in these fibres as has been shown for single, rabbit (Chiu et al. 1979) and rat (Brismar 1980) myelinated axons.

\section{b) Effects of GABA in 4-Aminopyridine}

The postsynaptic actions of GABA on rat sympathetic neurones in vitro have been described in detail (Adams and Brown 1975; Brown and Constanti 1978). As already discussed, the application of 4-AP resulted mainly in the spontaneous appearance of postsynaptic spikes. Since (1) the frequency of these spikes was clearly increased during the application of GABA, and (2) this effect was blocked by hexamethonium it would seem that this reflects a presynaptic action of GABA.

The precise presynaptic action of GABA in 4-AP is, as yet, unknown. However, assuming that 4-AP induces axonal membrane potential oscillations and/or action potentials (see above), a further GABA-induced axonal depolarization (Brown and Marsh 1978) would probably increase the likelihood of such oscillations exceeding threshold. This interaction would most probably occur on unmyelinated axons, since GABAreceptors are restricted to these fibres (Brown and Marsh 1978).

Regardless of the mechanism of the 4-AP/GABA interaction, the question remains as to whether GABA acts on the nerve terminals, the axonal membrane or both sites. The following points would seem to suggest an axonal site of action. a) A depolarizing action of GABA on sympathetic axons has already been described (Brown and Marsh 1978). b) The excitation of a single nerve terminal is probably not sufficient to release enough acetylcholine to induce a suprathreshold postsynaptic potential (cf Wallis and North 1978). c) GABA does not increase the frequency of miniature EPSPs, as would be expected of a terminal depolarization (Kato et al. 1980). Furthermore, the subthreshold potentials observed in the presence of 4-AP and GABA were also not miniature EPSPs, since they were blocked by TTX.

On the other hand, an axonal interaction might be expected to result in antidromic (hexamethoniuminsensitive) action potentials, which we have not yet observed.

The effect of GABA in 4-AP was replicated by 3APS and muscimol but not by glycine, taurine or glutamate. In addition, since bicuculline methochloride blocked the presynaptic actions of GABA, the receptors responsible for these effects appear similar to those occurring on rat unmyelinated axons (Brown and
Marsh 1978) and at postsynaptic sites in the mammalian peripheral and central nervous systems (Nistri and Constanti 1979). Baclofen, suggested to be an agonist at a second type of bicuculline-insensitive, peripheral, presynaptic GABA-receptor (Bowery et al. 1979), was ineffective in our experiments.

Acknowledgements. We are extremely grateful to Mr. K. Zinnhobler for programming the Nicolet computer and to Ms. E. Beuschel for skilled technical assistance. This research was supported by the Deutsche Forschungsgemeinschaft, grants $\mathrm{Br} 242 / 14$ and $\mathrm{Br} 242 / 16$.

\section{References}

Adams PR, Brown DA (1975) Actions of $\gamma$-aminobutyric acid on sympathetic ganglion cells. J Physiol 250:85-120

Bowery NG, Doble A, Hill DR, Hudson AL, Shaw JS, Turnbull MJ (1979) Baclofen: a selective agonist for a novel type of GABA receptor. Br J Pharmacol 67:444-445P

Bowman WC, Harvey AL, Marshall IG (1977) The actions of aminopyridines on avian muscle. Naunyn-Schmiedeberg's Arch Pharmacol 297:99-103

Brismar T (1980) Potential clamp analysis of membrane currents in rat myelinated nerve fibres. J Physiol 298:171 - 184

Brown DA, Marsh S (1975) A very simple method for recording ganglion depolarization. J Physiol 246:24-25P

Brown DA, Constanti A (1978) Interaction of pentobarbitone and $\gamma$-aminobutyric acid on mammalian sympathetic ganglion cells. Br J Pharmacol 63:217-224

Brown DA, Marsh S (1978) Axonal GABA-receptors in mammalian peripheral nerve trunks. Brain Res 156:187-191

Brown DA, Higgins AJ (1979) Presynaptic effects of $\gamma$-aminobutyric acid in isolated rat superior cervical ganglia. Br J Pharmacol $66: 108-109 \mathrm{P}$

Chiu SY, Ritchie JM, Rogart RB, Stagg D (1979) A quantitative description of membrane currents in rabbit myelinated nerve. $\mathrm{J}$ Physiol 292:149-166

Douglas WW, Ritchie JM (1957) On excitation of nonmedullated afferent fibres in the vagus and aortic nerves by pharmacological agents. J Physiol 138:31-43

Golenhofen K, Mandrek K (1978) Slow automatic activity in squid axons induced by 4-aminopyridine. J Physiol 284:69-70P

Heuser JE, Reese TS, Dennis MJ, Jan Y, Jan L, Evans L (1979) Synaptic vesicle exocytosis captured by quick freezing and correlated with quantal transmitter release. J Cell Biol 81 :275300

Hue B, Pelhate M, Callec JJ, Chanelet J (1978) Postsynaptic effects of 4-aminopyridine in the 6th abdominal ganglion of the cockroach. Eur J Pharmacol 49:327-329

Jankowska E, Lundberg A, Rudomin P, Sykova E (1977) Effects of 4-aminopyridine on transmission in excitatory and inhibitory synapses in the spinal cord. Brain Res 136:387-392

Kato E, Kuba K (1980) Inhibition of transmitter release in bullfrog sympathetic ganglia induced by $\gamma$-aminobutyric acid. J Physiol $298: 271-283$

Kato E, Kuba K, Koketsu K (1978) Presynaptic inhibition by $\gamma$-aminobutyric acid in bullfrog sympathetic ganglion cells. Brain Res 153:398-402

Katz B, Miledi R (1969) Spontaneous and evoked activity of motor nerve endings in calcium Ringer. J Physiol 203:689-706

Lemeignan M (1972) Analysis of the action of 4-aminopyridine on the cat lumbar spinal cord. 1. Modification of the afferent yolley, the monosynaptic discharge amplitude and the polysynaptic evoked responses. Neuropharmacol 11:551-558 
Lemeignan M (1973) Analysis of the effects of 4-aminopyridine on the lumbar spinal cord of the cat. II. Modifications of certain spinal inhibitory phenomena, post-tetanic potentiation and dorsal root potentials. Neuropharmacol 12:641-651

Llinás R, Walton K, Bohr V (1976) Synaptic transmission in squid giant synapse after potassium conductance blockade with external 3- and 4-aminopyridine. Biophys $J$ 16:83-86

Lundh H (1978) Effects of 4-aminopyridine on neuromuscular transmission. Brain Res 153:307-318

Lundh H, Thesleff S (1977) The mode of action of 4-aminopyridine and guanidine on transmitter release from motor nerve terminals. Eur J Pharmacol 42:411-412

Marshall IG, Lambert JJ, Durant NN (1979) Inhibition of aminopyridine-induced contractile activity in skeletal muscle by tetrodotoxin and by magnesium. Eur J Pharmacol 54:9-14

McAfee DA, Yarowsky PJ (1979) Calcium-dependent potentials in the mammalian sympathetic neurone. J Physiol 290:507-523

Meves H, Pichon Y (1977) The effect of internal and external 4-aminopyridine on the potassium currents in intracellularly perfused squid giant axons. J Physiol 268:511 - 532

Nicholson C, Steinberg R, Stöckle H, ten Bruggencate G (1976) Calcium decrease associated with aminopyridine-induced potassium increase in cat cerebellum. Neurosci Lett 3:315-319

Nistri A, Constanti A (1979) Pharmacological characterization of different types of GABA and glutamate receptors in vertebrates and invertebrates. Prog Neurobiol 13:117-235
Schauf CL, Colton CA, Colton JS, Davis FA (1976) Aminopyridines and sparteine as inhibitors of membrane potassium conductance: Effects on myxicola giant axons and the lobster neuromuscular junction. J Pharmacol Exp Ther 197:414-425

Tokunaga A, Akert K, Sandri C (1979) Three types of membrane modulation during transmitter release in rat spinal cord synapses. Neurosci Lett 12:147-152

Ulbricht W, Wagner H-H (1976) Block of potassium channels of the nodal membrane by 4-aminopyridine and its partial removal on depolarization. Pflügers Arch 367:77-87

Wallis DI, North RA (1978) Synaptic input to cells of the rabbit superior cervical ganglion. Pflügers Arch 374:145-152

Yanagisawa T, Satoh K, Taira N (1978) Excitation of autonomic nerves by 4-aminopyridine in the isolated, blood-perfused sinoatrial node preparation of the dog. Eur J Pharmacol 49:189192

Yeh JZ, Oxford GS, Wu CH, Narahashi T (1976a) Dynamics of aminopyridine block of potassium channels in squid axon membrane. J Gen Physiol 68:519-535

Yeh JZ, Oxford GS, Wu CH, Narahashi T (1976b) Interaction of aminopyridines with potassium channels of squid axon membranes. Biophys J 16:77-81

Received July 24/Accepted September 9, 1980 